\title{
The Universe and the Womb: Generation, Conception, and the Stars in Islamic Medieval Astrological and Medical Texts
}

\author{
LIANA SAIF (Oriental Institute, The University of Oxford)
}

\begin{abstract}
This article looks at the assimilation of Aristotle's account of 'coming-to-be' into conception theories found in Islamic medieval medical and astrological texts. It analyzes the way the four causes work on the level of the universe and that of the womb, and examines the reconciliation of ideas on planetary influence with the Galenic and Aristotelian theories of conception. The Arabic astrological theories that explain the receptiveness of human beings to astral influences provide the conceptual link between the macrocosmic and microcosmic processes. Conception becomes an individualization of the coming-to-be of species, and the stars act as agents of actuality in both processes.
\end{abstract}

Keywords: Conception, generation, semen, astral influences, causality, embryo

One of the main characteristics of ancient and medieval thought is the polysemy of knowledge: conceptual and theoretical parallels can be observed between different areas of study. This results from the belief in the unity of the universe. Such transferability is notable between the metaphysical theories of generation and the biological theories of conception, particularly when the development of the embryo is associated with specific planetary influences. Charles Burnett and Carmela Baffioni have explored the link between embryology and astrology in Medieval Islam, looking at the planet/pregnancy month correlation and astrological significations over pregnancy and the sex of the fetus. ${ }^{1}$ This article expands on their findings, and by studying Islamic medieval texts on astrology and medicine, it investigates the ways in which the Aristotelian four causes (material, formal,

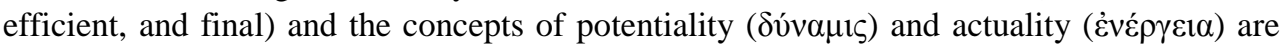
applied to conception theories. I argue that Arabic astrological theories that explain the receptiveness of human beings to astral influences provide the conceptual link between universal generation and conception. The coming-to-be of a child in the womb is an individualization of the coming-to-be of species that takes place on a universal level. Ultimately, in both cases, the stars act as efficient causes and agents of actuality.

1 BURnetT 1990, BAFFIONI 2005 (esp. 279-80), BAFFIONI 1998, BAFFIONI 1997. 
To investigate this macro-micro link, the first part discusses the Aristotelian theories of generation and links them with Aristotle's own conception theory and those of Hippocrates, Galen, and Ibn Sīnā (980-1037). The second part then examines embryology and conception in the context of astrology, looking primarily at the Rasāil of Ihwān alȘafā’ (The Epistles of the Brethren of Purity, tenth century), Abū Ma šar al-Balh̄̄̄ss (787886) Kitāb al-madhal al-kabīr ilā 'ilm ahkām al-nuğūm ('The Great Introduction to the Judgements of the Stars'), Pseudo-Apollonius' Sirr al-halìqa ('The Secret of Creation') and Halq al-ğanīn wa-tadbīr al-habālā wa'l-mawlüdīn ('The Creation of the Fetus and the Management of Pregnant Women and Newborns') by 'Arīb ibn Sa'd al-Qurțub̄e, the secretary of the Caliph al-Hakam II (r. 961-976).

\section{Generation and Conception in Ancient Authorities}

Aristotle defines generation as an unqualified coming-to-be of a substance (coming-to-be simpliciter). ${ }^{2}$ Qualification determines the nature of an object. He explains, "in one sense, things come-to-be out of that which has no being without qualification; yet in another sense they come-to-be always out of what is. For there must pre-exist something which potentially is, but actually is not; and this something is spoken of both as being and as notbeing". ${ }^{3}$ In the first sense, things are identified by negation (not white, not round, etc.) whereas in the second sense they are recognized by what they potentially can be but not actually are. Coming-to-be is a change from potential substance to actual; and there are two kinds of substances: primary substances are those that cannot be predicated of another thing (Socrates), and secondary substances are universal and can be predicated (Man). ${ }^{4}$

Actualization results from the participation of the four causes in the process of generation: the material, the formal, the efficient, and the final. Matter (vँ $\lambda \eta$ ) "is to be identified with the substratum which is receptive of coming-to-be and passing away". 5 The four couplings of elements: hot dry, hot moist, cold dry, cold moist, attach themselves to the "simple" bodies of Fire, Water, Earth, and Air. ${ }^{6}$ These bodies themselves come-to-be, and they change into one another in a process of conversion which is cyclical, perpetually creating the bodies of all things. ${ }^{7}$ A substance is a compound of matter shaped by form ( does not see to exist abstractly from matter, the potential component. The efficient cause which leads to the emergence of the substance is a continuous motion, rendering comingto-be a cyclical process. ${ }^{8}$ The motion of the whole (primary motion) does not generate but the motion along the inclined circle does (the region about the center-between eternal and

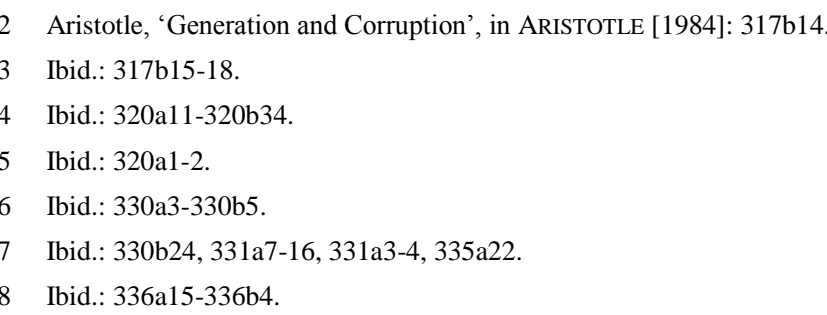


mortal, between primary motion and individual motion, between God and Earth). ${ }^{9}$ It is a motion that possesses the necessary continuity and duality of motion so that coming-to-be and passing-away can occur. Therefore, it is not singular since these two processes are contrary, needing a duality of motion. This motion is instigated, however, by the motion of the whole. ${ }^{10}$ Aristotle here is addressing universal coming-to-be: "God therefore adopted the remaining alternative, and fulfilled the perfection of the universe by making coming-tobe uninterrupted; for the greatest possible coherence would thus be secured to existence, because that 'coming-to-be should itself come-to-be perpetually' is the closest approximation to eternal being." "11 Thus, perpetual motion and cyclical material conversion create a "readiness" that God utilizes for the creation of species.

Aristotle's seeming inconsistency regarding the identification of the substantial form as species or individuals puzzled and divided his interpreters. It is not the concern of this section to resolve this problem; however, Aristotle's conception theory, as found particularly in the Generation of Animals, is helpful as it is concerned with the coming-tobe of individuals in the strict sense. The text begins with the exposition of the four causes. ${ }^{12}$ According to Aristotle, both the male and the female are "origins/principles of generation"

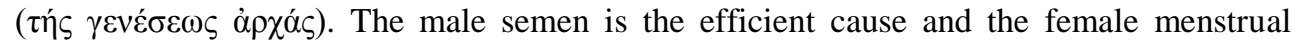
blood is the material cause. ${ }^{13}$ The male semen acts as an efficient cause by imparting motion, though it does not at all partake in the material composition of the fetus. In addition, the male semen gives soul and vital heat, leading to the actualization of the generation of the fetus. Aristotle implies that the male semen is of a divine nature unlike the menstrual blood which is akin to primitive matter. ${ }^{14}$ The union of the male semen and menstrual blood is the beginning of the embryo: an individual generation of substance. ${ }^{15}$ What follows is alteration and growth. In On Generation and Corruption, the former is defined as a change in quality and the former in magnitude. An embryo is thus a primary substance which proceeds to receive qualification through alteration - the emergence of organs, bones, limbs etc. - and then experiences growth. ${ }^{16}$ This process began as a result of the readiness of the principle of actualisation and motion (semen) and the material principle (menstrual blood), parallel to the readiness of the universe to generate due to perpetual motion and material conversions.

Galen famously contested Aristotle's theory of conception, rejecting the assignation of efficient causality exclusively to the male principle, and material causality to the female principle. According to Aristotle, "it is not necessary that anything at all should come away from the male, and if anything does come away it does not follow that this gives rise to the embryo as being in the embryo, but only as that which imparts the motion and as the

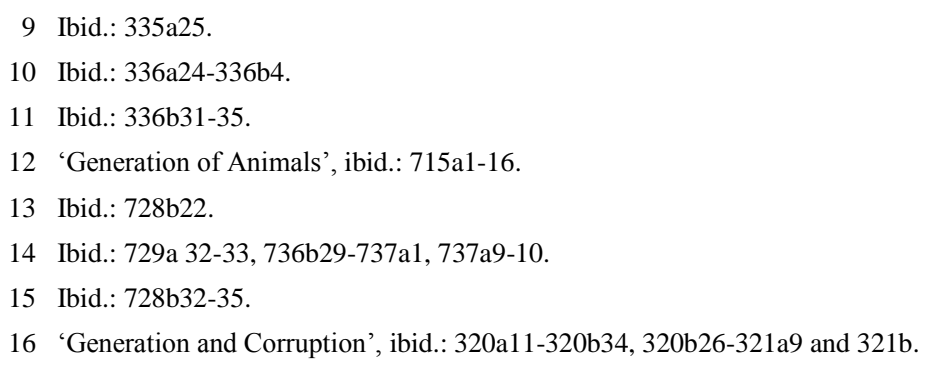


form" ${ }^{17}$ Galen, however, argues that the male semen does in fact contribute to the matter of the embryo; it remains in the uterus physically and forms the membrane which holds together the embryo; ${ }^{18}$ a view established by Hippocrates in the Nature of the Child. ${ }^{19}$ This viscous and thick membrane gets attached to the mouths of the uterus vessels as a result of the womb's contraction. Moreover, veins, arteries and nerves are generated from the male semen. ${ }^{20}$ Galen, following Hippocrates, also contests Aristotle's denial of the existence of female semen and rejects his reduction of the female principle of generation to menstrual blood as a purely material cause. The male semen, when it falls on the fundus of the uterus, has an irregular shape unable to coat the entire uterus, "nature coats it with a second semen, that of the female" that is produced from a spermatic vessel which takes its start and is attached to "the testicles of the female": ${ }^{21}$

When, therefore, the female produces semen at the same time as the male, the semen discharged through each of the two horns and carried to the middle of the hollow of the uterus coats the passages and at the same time reaches the male semen. It mixes with the semen, and the membranes are entwined with each other [...] the female semen provides this service for the fetus and becomes, as it were, a kind of nutriment for the semen of the male; for it is thinner than the male semen, colder, and more suitable than all else for nourishment. ${ }^{22}$

Thus for Galen the female and the male both contribute matter and power; semen (male and female) is not only an efficient cause but also material; and since the embryo draws blood and pneuma from the menstrual blood, it is not only a material cause but also a kind of efficient power. ${ }^{23} \mathrm{He}$ accedes, however, that "both the semen and the menstrual blood have both principles, but not with matching strength, the semen having the strongest active principle but a very small amount of the material principle, whereas in the blood the material principle is most abundant and the dynamic very weak. ${ }^{24}$

The Galenic-Aristotelian polemic notwithstanding, the universal causes of generation, form, matter, and motion, are paralleled in the conception of the fetus. According to Aristotle, these are the universal counterparts, respectively, of the male semen, menstrual blood, and motion of the semen. To Galen, the material cause is a combinatory contribution of male semen (embryo's membrane), female semen (similar to the amnion), and the menstrual blood. The actualizing principles (motion and soul) are derived from both the semen and the menstrual blood. Aristotle, as an epigenist ${ }^{25}$ perceived that the alteration in

17 'Generation of Animals', ibid.: 729b9-21.

18 GALEN [1992]: 75-7.

19 HiPPOCRATES [2012], x: 31, 35.

20 GALEN [1992]: 79.

21 GALEN [1992]: 87, 145.

22 GALEN [1992]: 87.

23 GALEN [1992]: 165.

24 GALEN [1992]: 165.

25 That is of the belief that the formation of the fetus's parts and organs do not develop from pre-existing forms but are actualized gradually and internally. 
the quality of the fetal substance gradually develops the specific form of the individuals. The individualization, then, of the substantial form is an internal, physical and biological process of alteration and growth that takes place in the womb: "for the end is developed last, and the peculiar character of the species is the end of generation in each individual". ${ }^{26}$

Ibn Sīna revises the Galenic and Hippocratic conviction that both men and women produce semen and Aristotle's belief that menstrual blood is the only female generative principle. In his discussion on the generation of animals, Ibn Sīnā explains that both men and women have generative principles that are commonly given the name "semen". However, only the male principle can really be called semen, and the female principle is a moisture that "is closer to the essence of men's semen than the rest of the menses", and it aids the motion of semen essential for conception. ${ }^{27}$ The male semen contains the generating power (quwwa muwallida) and the female "semen" has a reproductive power (quwwa mutawallida). ${ }^{28}$ The first power imparts form (musawwira), and the second power is form-accepting (mutașawwira). ${ }^{29}$ The body of the semen itself disperses because it imparts form qualitatively, whereas the female power functions materially and quantitatively. ${ }^{30}$ The union of the seminal form and moisture is the beginning of conception, after which the menstrual blood provides the body of the embryo and proceeds to nourish it.

As Aristotle, Ibn Sīnā's biological exposition of the development of the fetus can be correlated with his own metaphysics. The difference between the generating power of male semen and the reproductive power of female moisture can be understood in terms of Ibn Sinā's concepts of subject $(m a w d \underline{u} \overline{)})$ and receptacle $\left(\right.$ mahall $\left.{ }^{31}\right)$. The subject is "that which becomes subsistent in itself and, in terms of being the species, becomes thereafter a cause for something to subsist in it ([but] not as part of it)". ${ }^{32}$ This is applicable to the power of male semen whereby form is imparted only, without any actual material contribution, determining the species of the embryo. Ibn Sinna refers to the function of the sperm in his metaphysical discourse to demonstrate the relationship between the subject and the receptacle: "As for the father, he is the cause for the movement of the sperm. The motion of the sperm, in the above mentioned way, is a cause of the occurrence of the sperm in the womb. Its occurrence in the womb is then a cause for something. As for its becoming formed as an animal and its continuity as animal, [this] has another cause. If this, then, is the case, then every cause coexists with its effect". ${ }^{33}$ This simultaneously reciprocating cause is the receptacle which "is anything in which something dwells [and which] becomes, by virtue of that [indwelling] thing, [the possessor] of a certain state". ${ }^{34}$

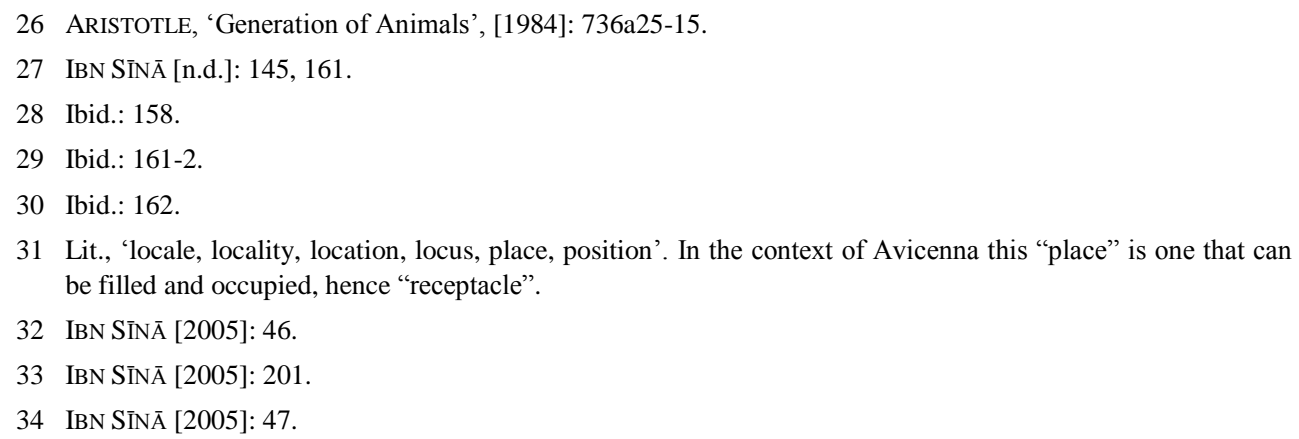


When the form is accepted by female moisture, a readiness for actualization is established which is followed by substantiation. For Aristotle, the form in the male semen is transferred into the menstrual blood, rather than female moisture, after which the body of the semen disperses. But according to Ibn Sīnā, corporeal form cannot exist separated from matter. ${ }^{35}$ Thus it is an adherence to this rule, that a form-accepting material (moisture) which has received form through union with the form-giving semen is then nourished by menstrual blood. Even though the body of the semen is shed away after this coagulation, materialisation remains uninterrupted. As for the soul, according to Ibn Sinnā it is the male semen that imparts it to the fetus. ${ }^{36}$

From this survey of generation and conception theories, we note that though Aristotle himself did not fully explain how the universal process of generating substances and the coming-to-be of species particularizes into the generation of an individual in the womb, his discussion of conception, and those of Galen and Ibn Sīnā revolved around causality, actuality, and motion. They applied metaphysical and universal notions pertaining to generation to the biological process of conception. However, it is in astrological texts and medical works that incorporated astrological theories that we find a clear articulation of the link between the macrocosm and the microcosm, between universal generation and conception. In these texts, the stars are the actualizing principles of the generation of species and individuals.

\section{The Stars}

In On Generation and Corruption, Aristotle asserts that the male and the female "are first principles of generation. For by a male animal we mean that which generates in another, and by a female that which generates in itself; that is why in the macrocosm also, men think of the earth as female and a mother, but address the heaven and the sun and other like entities as progenitors and fathers". ${ }^{37} \mathrm{He}$ also ascribes a divine nature to the efficacy of the male semen for imbuing the embryo with soul. ${ }^{38}$ Aristotle explains that the vital heat imparted by the male semen to the embryo "is the breath included in the semen and the foam-like, and the natural principle in the breath, being analogous to the elements of the stars". ${ }^{39}$ With this, in addition to associating material passivity with femaleness and formal actuality with maleness, Aristotle hints at the parallel between the macrocosmic process of generation and the microcosmic process of conception.

Matter is receptive, passive, and feminine - as the earth - characterizing the generated and corruptible world; efficiency is masculine, incorruptible, and divine - as the heaven. In On Generation and Corruption, Physics, and Meteorology Aristotle sees the circular motion of the celestial spheres as the efficient cause of the generation of species and

\footnotetext{
35 IBN SīnĀ [2005]: 57, p. 63.

36 IBN SīnĀ [n.d.]: 166-7.

37 ARISTOTLE, 'Generation of Animals', [1984]: 716a11-16.

38 ARISTOTLE [1984]: 736b22-26.

39 ARISTOTLE [1984]: 736b29-737a1.
}

$J A I S \cdot 16$ (2016): 181-198 
considers it responsible for the transformation and alteration of the elements and simple bodies. ${ }^{40}$ However, celestial efficient causality is more fully explicated in Arabic early medieval texts on astrology such as those of Abū Ma šar al-Balhīi. This is demonstrated on three levels: the role of the stars in generation and corruption, their role in conception, and, finally, their impact on the development of the fetus.

Abū Ma šar al-Balhī explains in his Kitāb al-madhal al-kabīr that the heat from the motion of the celestial spheres constitutes the efficient cause that specifically unites form and matter, body and soul. ${ }^{41}$ Astral influences determine both primary and secondary substances, that is, the individual and the species. In contrast, Aristotle, as we have seen, considers the individualization of the substantial form as strictly internal and biological. Concerning the human individual, Abū Ma ${ }^{c}$ šar posits that, in addition to the material cause which is responsible for the elementary composition and humoral inclinations of an individual, and the formal cause which determines 'humanness', ${ }^{42}$ there are astral causes:

As for that which is affected in him due to the powers of the motions of the planets - by permission of God - that is not related to the elements or form, it is manifest and it is [determined by] their [the planets'] significations over the particularity of his genus and individuality among the rest of the genera and individuals; and [it is determined by] their significations over the composition of all natural things, the commixing of the form and elements in elemented things, the harmony between the animal and rational souls with the body, and other things like beauty and ugliness, height and shortness, maleness and femaleness, colors, motions, bravery and cowardice, good behavior, fatness and slimness, abrasiveness and softness. ${ }^{43}$

Abū Ma šar argues that the planets collaborate in the process of generation and thus establish a causal and semiological connection with the humors, organs and the properties of minerals, plants and animals. Consequently, the planets influence "the emergence of a human from seed". ${ }^{44}$ In his De radiis, Yacqūb ibn Ishāa al-Kindī, philosopher and contemporary of Abu Ma šar, accepts that the diversity of species and members is determined by the diversity of astral rays. In the generated world, al-Kindi writes, the formed matter of the seed changes into the formed matter of the barley. The variations of individualistic characteristics are determined by the variation in aspect, direction, time, and place of the rays. ${ }^{45}$ This is an epigenic stance which accepts an external factor (stars) acting on formation rather than it being an exclusively internal and biological process, as Aristotle posits.

\footnotetext{
40 ARISTOTLE, 'Generation and Corruption', [1984]: 338a19-338b1; 'Physics', [1984]: 200b12; 'Meteorology', [1984]: 339a15-24, 340a20-1.

41 SAIF 2015: 9-45.

42 al-BALH̄i [1995-96], II: 26.

43 al-BALHī [1995-96], II: 27.

44 al-BALHĪ [1995-96], II: 28-9, 259; BAFFIONI [2005]: 279-80; BAFFIONI [1998].

45 ADAMSON \& PORMANN [2012]: 224-5. The Arabic original of De radiis is lost but a Latin translation was very influential in the European Middle Ages and the Renaissance; See SAIF [2015]: passim.
} 
As a result of astral causality in the generation of individuals, conditions of conception and the nature of the conceived often have astrological indications. For example, in a section concerned with the astrological houses, Abū Ma`šar explains that the first house, which is the ascendant, incorporates the properties of Saturn because it is the highest and first of the seven planets. So, this house has signification over darkness, conception, and "over bodies as long as they are inside the womb". ${ }^{46}$ In a chapter on the properties of planets, we are informed that Mars signifies "the motion that is before the time of women's delivery" in addition to abortion and difficult pregnancies. ${ }^{47}$ Astrological-Hermetic lots $(\mathrm{sahm} / \mathrm{suhum})$ also influence the development of the fetus; for example, it is in the lot of "female progeny" that one may discover the sex. If it falls in a masculine sign, it is male; if in a feminine sign, it is female. ${ }^{48}$ Moreover, the lot of "steadiness and continuity" indicates the appearance of the fetus and its parental resemblance. ${ }^{49}$ These do not only demonstrate the semiological link between the planets and the fetus, but they are also justified by the causal role the planets have in generation and conception.

The most explicit and elaborate expression of the interconnection between universal generation and conception, however, is found in pseudo-Apollonius' Sirr al-haliqa ('The Secret of Creation'). It contains sections that correspond with late ancient texts such as the Syriac Book of Treasures (Kitāb al-dahāìir) of Job of Edessa (Ayyūb al-Ruhāwī, d. 835), De natura hominis (Kitāb fì țabì at al-insān) by Nemesius of Emesa, and the Hermetic Istimātīs. The date of this text has been a matter of speculation, but Ursula Weisser suggests that a short version was translated from Greek as early as the eighth century. ${ }^{50}$

Sirr al-haliqa elucidates the concept of nutfa (seed, semen) at the macrocosmic and microcosmic levels. The nutfa is the substantial inception of everything; the first physical reality that leads to the full materialization and actualization of the generated. Everything, primary or secondary, begins from a nutfa. On a universal level:

Everything is from the four natures: heat, cold, moisture, and dryness; the natures are in all things; things are connected to them; and they are connected to each other. They all turn in a single cycle, encompassed by a single system in which one sphere turns. The highest among them are connected to the lowest, and the nearest among them are connected to the most remote, because they are all from one essence-one $n u t f a$ - having in common one nature with no variation in them until accidents predicate them. ${ }^{51}$

The author explains that the motion of the celestial sphere is the active and efficient cause of the generation of all minerals, plants, and animals and their composition. ${ }^{52}$ The elements,

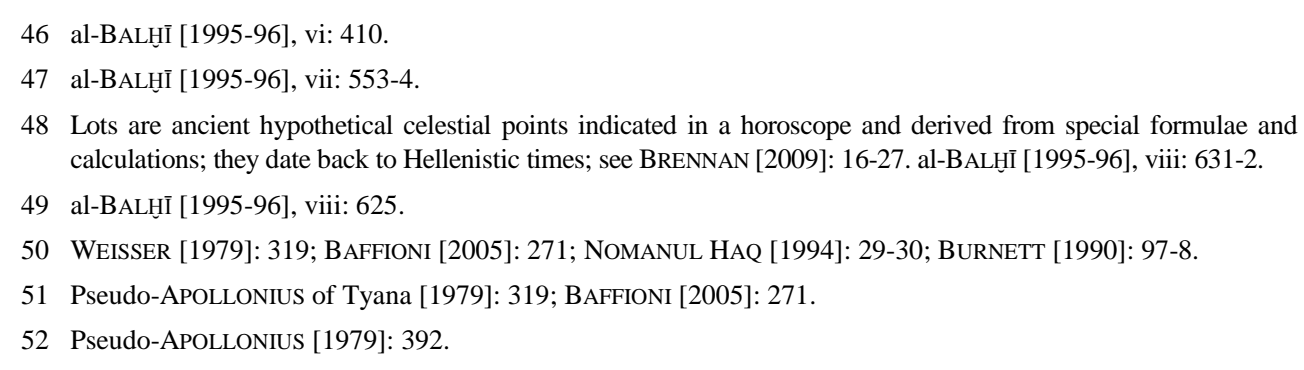


on the other hand, are 'mothers' (ummahāt): passive and receptive. ${ }^{53}$ However, he differentiates between primary composition (al-tarkīb al-awwal) whereby species are generated on the universal level, and secondary composition whereby individuals are produced on the terrestrial level. When the sphere moves and revolves "the thick" mixes with "the subtle" and the four natures are produced. On their own they are weak and so through the same motion they join and, as a result, the four elements and the three genitura (mawālìd: minerals, plants, and animals) emerge whose species are determined by the astral cause. ${ }^{54}$ As this is a primary archetypal process, it cannot be repeated and so members are generated from their species through a secondary process. ${ }^{55}$ In a crucial passage the author explains:

And an example of this is Man, who is the small world, similar to the big world. For he came-to-be first from the [four] natures, and since this [primary] composition is over and this process has passed, [now] a human cannot be generated except from [another] human. And so a human is generated from the nutfa of [another] human. It is a small nutfa containing many powers, and so many people emerge from it as he [the first Man] first emerged from the natures, I mean by this the [primary] composition. ${ }^{56}$

Following Hippocrates and Galen, rather than Aristotle, pseudo-Apollonius accepts the existence of the female semen. The meeting of 'the thick' and 'the subtle' that leads to the emergence of the universal nutfa is reflected in the womb by the meeting of the thick and viscous male semen and the thin female semen. ${ }^{57}$ The essence of the female semen is like that of male semen but different in velocity and complexion; they also contribute equally to imparting form and shape. According to pseudo-Apollonius, "the wombs of women are their penises having been reversed". 58

Another important discussion of conception and its relation to universal generation is found in Ihwān al-Șafā's epistle on conception (Masqat al-nutfa). It begins with declaring that the celestial world is the efficient cause of all generation, particularly the Universal Soul-a Neoplatonizing gesture. At the time of conception, the Universal Soul pours into the embryo a particular soul; ${ }^{59}$ hence they disagree with Aristotle who insists that the soul or the vital principle of the embryo cannot be external and is given only by the male semen. However, the Ihwān seem to consider the female generative principle to be only menstrual blood rather than a second type of semen, thus conforming to the Aristotelian theory of conception in this aspect. ${ }^{60}$

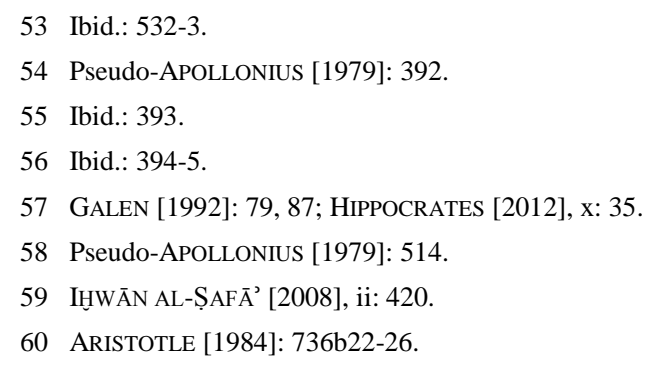


According to the Ihwān, the four elements constitute the formal and material causes. Here too the elements are referred to as mothers. ${ }^{61}$ Generation is likened to the process of making butter; "it is like milk in a container and the motion of the spheres is the churner and the resulting creatures are the butter". ${ }^{62}$ This is based on the milk allegory used by Aristotle to illustrate the function of the male semen in conception:

What the male contributes to generation is the form and the efficient cause, while the female contributes the material. In fact, as the coagulation of milk, the milk being the material, the fig-juice or rennet is that which contains the curdling principle, so acts the secretion of the male, being divided into the parts in the female [...] the female does not contribute semen to generation, but does contribute something, and that this is the matter of the menstrual flow, or that which is analogous to it in bloodless animals, is clear from what has been said. ${ }^{63}$

This is the same metaphor Galen also refers to in order to demonstrate that male semen contributes to the materiality of the embryo. He declares the folly of the Peripatetics who hold the opinion that the male semen in conception imparts only motion and the psychic principle and is then ejected. ${ }^{64}$ The body of the semen cannot be expelled, in the same way that fig-juice or rennet does not evaporate when it curdles the milk. ${ }^{65}$ The Ihwān, thus, use the milk allegory found in the context of conception and extend it to the universal process of generation, thus equating the efficiency of the male semen to that of astral influences.

The milk allegory is reiterated in G'âyat al-hakim ('The Goal of the Wise'), a text on magic known in the Latin tradition as the Picatrix by Maslama al-Qurtubī (d. 964) and greatly influenced by the Epistles. ${ }^{66}$ The milk allegory and the coagulation of blood and semen are used as part of the author's metaphysical interjections which assert that the sympathies and connections among everything are the result of astral causation. AlQurțubī, like Aristotle and the Ihwān, considers the principles of generation to be blood and male semen. He aligns himself with the Peripatetics, criticized above by Galen, and writes:

And know, may God illuminate your perception, that the organs whereby reproduction occurs are two. One gives the matter that makes up the animal to whom this power belongs, and the other gives the form of the species and motion to matter, until the form is completed by it [motion]. For the power that gives matter is

\footnotetext{
61 IHWWĀN AL-ȘAFĀ’ [2008], ii: 417, 419.

62 IHWWĀN AL-ṢAFĀ’ [2008], ii: 419.

63 ARISTOTLE [1984]: 729a 9-22.

64 GALEN [1992]: 69

65 GALEN [1992]: 71

66 FIERRO [1996]: 87-112. Al-Qurțubī copies sections from the Rasā̉il almost verbatim; for example, compare the definition of magic in al-QURṬUBI [1933]: 6-7 with IHWWĀN AL-ṢAFĀ' [2008], iv: 314; also compare the significance of the moon in al-QURṬUBĪ [1933]: 67-70 with IHWĀN AL-ȘAFĀ' [2008], iv: 335. It was accepted that the Rasā'il were probably brought to al-Andalus by Abū l-Hakam b. 'Abd al-Raḥmān al-KIRMĀNĪ (d. ca. 1075), but FIERRO confirms al-QURȚUBĪ, the author of the Ġāyat al-hakìm, as the one responsible for their introduction. See 'AFīFī [1933]: 7; EBSTEIN [2014]: 29-30. Confirming the attribution of the Ghāya to alQURṬUBI and the transmission of the Rasā'il by him, see DE CALLATAŸ [2013].
} 
the power of the female, and that which gives the form is the male power [...] when semen arrives into the womb and there encounters blood prepared by the womb to accept human form, this semen gives this blood a power whereby it moves, until the organs of the human, the form of every organ, and generally the human form, emerge from this blood. For the blood prepared in the womb is the matter of the human and the semen is this matter's mover until form emerges in it. The action of the semen on the blood is the [same] action [as] rennet that coagulates milk. Rennet is the cause of the coagulation but itself is not part of that which is coagulated or matter. So is semen, it is not part of that which is coagulated in the womb or matter, and the fetus comes-to-be from semen the way curd comes-to-be from rennet [...] know that this maleness (duküriyya) is the efficient cause of plants and animals. ${ }^{67}$

This is preceded by a discussion of love and desire, with an allusion to their astrological determiners which have an impact on the potency of semen. ${ }^{68}$

Like Galen and Ibn Sīnā, the theories of Abū Ma šar, pseudo-Apollonius, and the Ihwān are founded on Aristotelian notions of causality, motion, and actuality. They argue that astral causation actualizes generation in the universe and conception in the womb; the former process presented as a continuation of the latter. However, this is not the only way in which the stars and planets are incorporated in theories of conception. The development of the embryo itself is regulated by them.

The traditional stages of the formation/gestation of the individual are described by Galen:

1) The female and male semens mix. "Hippocrates the all-marvelous" does not consider it a fetus but a semen.

2) It is filled with blood. The heart, brain and liver are still unarticulated and unshaped. The fetus has by now a certain solidity and considerable size. The substance of the fetus has the form of flesh and no longer the form of semen. ${ }^{69}$

3) It is possible to see the three ruling parts more clearly, that of the stomach more dimly, and much more still that of the limbs. Later on they emerge as "twigs", as Hippocrates calls them. ${ }^{70}$ Flesh grows and fattens. Bones are generated from drying heat. ${ }^{71}$

4) All the parts and the limbs are differentiated, becoming a child. ${ }^{72}$ Here Hippocrates treats it as animal but Galen follows Aristotle and believes the fetus receives a nutritive soul before the sensitive and/or rational. ${ }^{73}$ The fetus first of all receives the vegetative power. $^{74}$

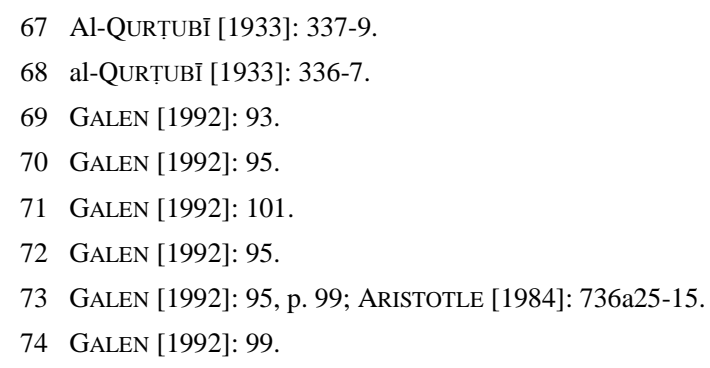


For Ibn Sīnā, the fetus begins as a nutfa (the coagulation of female moisture and male semen) which develops into a 'alaqa (blood-clot) when the embryo is nourished by blood after it attaches itself to the veins of the womb. Then it is enfleshed becoming a mudga, and after this stage the organs are formed and the limbs stretch out. ${ }^{75}$ The significance of this description is not merely obstetric. It interprets a mysterious passage in the Qur'ān:

We created man from the essence of clay (suläla min tīn), then made him a sperm (nutfa) in a well-guarded cavity (qarār makinn), the sperm We turned into a blood clot ('alaqa), the blood clot into a morsel (mudga), the morsel into bones, the bones We clothed with flesh, and then We reared him into another creation, Blessed in God, the most excellent of Creators! ${ }^{76}$

The Qur'ānic terminology and description of gestation become standard in medical work, elucidating the harmony between the macrocosm and the microcosm and between revelation and science. ${ }^{77}$ For example, in his Firdaws al-hikma ('Paradise of Wisdom') the physician Abū 'l-Hasan 'Alī ibn Sahl Rabban al-Ṭabarī (838-870) writes that in the first 16 days of conception the fetal substance is a froth and after 14 days it becomes a calaqa (blood clot), and in 26 days it turns into a mudga. This is also followed by a description of man as microcosm. ${ }^{78}$

Astral influences were introduced to the stages of gestation, and perhaps the earliest text to do so in medieval Islam is Sirr al-halīqa. Each stage in the development of the fetus comes under the activity of a specific planet, following the order of the celestial spheres. When the female and male semens mix, the nutfa is still and comes under the activity of Saturn because it is cold and dry, and it is the slowest, and coldest of planets. The nutfa stays still for an hour then it undergoes putrefaction ( f $^{\text {' f }}$ in); the heat of putrefaction renders it yellowish; this happens in seven days, going through the influence of all the seven planets. After which it reddens and becomes 'alaqa (blood clot, leech-like) and is strengthened by nourishing blood for 30 days. It is enfleshed by this process which lasts for 60 days under the influence of Jupiter. ${ }^{79}$ It is at this stage that the head, eyes, nose, mouth, ears and hair are formed. ${ }^{80}$ In the next 90 days, the human form is completed and strengthened under the rule of Mars because of its intense heat. Then the Sun takes over and life becomes manifest externally, and this happens over 120 days after which the fetus falls under Venus and the bones begin to harden, veins appear, flesh, fat, and skin grow. It remains under the influence of Venus for 150 days. ${ }^{81}$ For the next 180 days, Mercury

75 IBN SīNĀ [n.d.]: 166-72.

76 The Qur'ān [2008], xxiii: 12-17.

77 Musallam 1990: 32-46; TOELle 2003: 367-81, 371. - Toelle highlights all Qur'anic references to the creation of Man and proposes, inconclusively, Ancient Egyptian and Mesopotamian mythical origins. For example, she relates the assignation of passivity to the female earth and activity to the male $m \vec{a}^{\text {' }}$ (meaning both rain and semen in the Qur'ān) to the Ancient Egyptian myth of the creation of Shu and Tefnut from the semen of Atum.

78 al-ṬABARĪ [1928]: 32, 48-9, 541.

79 Pseudo-APOLLONIUS [1979]: 515.

80 Ibid.: 516

81 Ibid.: 517.

$J A I S \cdot 16(2016): 181-198$ 
increases the movement of the fetus. ${ }^{82}$ Then, in the seventh month, it falls under the Moon: the fat is whitened, the flesh is reddened and blood flows into all the parts of the body. The eighth month is particularly perilous because the fetus is now under the rule of Saturn again; it is still and cold as the planet and so if it is born in this month it will likely die. The ninth month belongs to Jupiter and the baby now is nurtured and complete, being under its benefic influences. $^{83}$

Ihwān al-Ṣafā' also illustrate the stages of gestation. In the first stage, the male nutfa settles in the womb. The soul of the individual is endowed at this stage, which contradicts the opinions of Aristotle and Galen to whom it is imparted at a later stage. In the second stage, the vegetative soul attracts the menstrual blood to the nutfa and heats it, becoming a 'alaqa "coagulating like rennet coagulates milk" ${ }^{84}$ The planet Saturn rules this stage/month, because it is the highest planet, the place of noble essences and the fount of spiritual and intellectual powers. Saturn is heavy and cold, holding the 'alaqa in place. Below is a table of the Brethren's planet/month correlation: ${ }^{85}$

$\begin{array}{cl}\text { Month } & \text { Planet } \\ 1 & \text { Saturn } \\ 2 & \text { Jupiter } \\ 3 & \text { Mars } \\ 4 & \text { Sun } \\ 5 & \text { Venus } \\ 6 & \text { Mercury } \\ 7 & \text { Moon } \\ 8 & \text { Saturn } \\ & \\ 9 & \text { Jupiter }\end{array}$

Effect

The coagulation of the semen, giving essence.

Gives heat to the 'alaqa.

Gives more heat and motion, turning the 'alaqa into a mudga

The animal soul enters because the Sun is the chief of all planets and its soul is the spirit of the universe.

Completes the form of the fetus and the organs become more apparent. However, it remains coiled into one mass.

The fetus moves, kicks, spreads out, opens its mouth, turns its tongue, sleeps and is awakened.

Fattens and straightens the fetus. Organs are strengthened and joints hardened.

The fetus becomes still and heavy, cold and sleepy. If a child is born in this month it will be sluggish, live a short life, or even be stillborn.

82 Ibid.: 518.

83 Ibid.: 519. To the list of early astro-gynecological texts we can add the pseudo-Galenic text De spermate surviving presently in 42 Latin manuscript and a Middle English translation. Its origin is unknown but a late antique provenance has been suggested; MERISALO \& PAHTA [2008]: 91-92; PAHTA [1998]. It is asserted in this text that the stars have strong influence on the male and female semens, the womb, and the physical development and characteristics of the infant; BURNETT [1990]: 97. Some ideas in De Spermate, particularly its account on the medical spirits, have been linked to the Pantegni of Constantine the African (d. before 1098/9) which is an adaptation of Kitāb Kämil al-șinā'a al-țibbiyya ('The Complete Book of the Medical Art') by 'Alī ibn al-'Abbās al-MAĞŪsī (d. 994); BURNETT [1994]: 101.

84 IHWWĀN AL-ȘAFĀ’ [2008], ii: 421.

85 IHWWĀN AL-ȘAFĀ’ [2008], ii: 423-6. 
We find a similar discussion of conception and the role of the planets in a pediatric treatise entitled Halq al-ğanìn wa-tadbìr al-habālà wa'l-mawlüdīn ('The Creation of the Fetus and the Management of Pregnant Women and Newborns') by 'Arīb ibn Sa'd al-Qurțubī, the secretary of the Caliph al-Hakam II (r. 961-976), to whom the treatise is dedicated ${ }^{86} \mathrm{Al}$ Qurtubī follows Galen and is of the opinion that women produce semen. The strength of desire in one parent determines which semen dominates and therefore the child's resemblance to the mother or the father ${ }^{87}$ Referring to Hippocartes' Book on the Nature of the Child and the Book of the Embryo, ${ }^{88}$ al-Qurtubī also explains that the womb consists of two cavities and two "horns" (fallopian tubes) at the ends of which are the female testicles. During sex, the horns shake, dropping the seed (zar $).{ }^{89}$ Conception occurs when the female and male semens meet, forming the nutfa which becomes foam-like in six days, then bloodlike (šibh damm) after fourteen days. It grows into a mudga after 26 days and develops a navel through which it derives nourishment, blood, and breath from the mother. Al-Qurțubī then discusses the debate between Aristotle and Hippocrates concerning the first vital organ to develop in the fetus: the former contends it is the heart, the latter the brain. After this, the fetus "branches out" like a tree and continues to grow. ${ }^{90}$

This is followed by a chapter on the duration of pregnancy which begins with accounts of Hijazi women carrying children for 30 months and longer, and monstrous pregnancies and births. ${ }^{91}$ Concerning seven-month pregnancies, al-Qurțubi states that the Umayyad Caliph 'Abd al-Malik ibn Marwān (r. 685-705) was a "sevener", and so was the poet Jarīr (c. 650- c. 728). ${ }^{92}$ The fetus is complete and strong in the seventh month, therefore birth during this month is not risky. He provides an astronomical justification. There are two turning points (buhrān) in the development of the fetus: "if the year witnesses a whole turn (dawr) of the cycles of the spheres, in it comes a powerful turning point; [as a result], change and motion manifest in the bodies. Half the year is also a turning point because it would be half a turn". If the fetus completes half a solar year it becomes strong and can be safely delivered. ${ }^{93}$ As for the dangers of birth on the eighth month, it is explained medically and astrologically. If the baby is not delivered in the seventh month, then, in the eighth month, it will be weak and exhausted, have tumors, and suffer pain from the motions of the seventh month; therefore it will more likely die. Jesus Christ is an eight-month baby;

86 НітснСОск [1990]: 70-78, particularly 75-7.

87 al-QuRṬUBĪ [1956]: 8-10.

88 Kitāb al-ağinna ('The Book of Embryos') is a Hippocratic adaptation and paraphrase conflated with commentary by a certain Ibn Šahda al-Karhī as mentioned by Ibn Nadīm. It is also referred to by the Abbasid physician and translator Hunayn ibn Isḥāq (809-873) as Tabī'at al-ğanīn ('The Nature of the Emryo'). It contains ideas from On Semen, On Generation, and the Nature of the Child; see HIPPOCRATES [1978]: i-ii, vi.

89 al-QurṬuBī [1956]: 18.

90 al-QuRṬUBī [1956]: 29-30.

91 al-QURṬUBī [1956]: 34.

92 al-QURṬUBī [1956]: 36.

93 al-QURṬUBī [1956]: 36.

$J A I S \cdot 16(2016): 181-198$ 
becoming "a sign for the people", anticipating his miraculous ascendance. ${ }^{94}$ For the astrological explanation, al-Qurțubī uses the planet/month correlation: ${ }^{95}$

\section{Month Planet}

1 Saturn (cold dry)

2 Jupiter (hot moist)

3 Mars (hot dry)

$4 \quad$ Sun (hot dry)

$5 \quad$ Venus (cold dry)

6 Mercury (moderately hot and dry)

$7 \quad$ Moon (cold wet)

$8 \quad$ Saturn (cold dry)

$9 \quad$ Jupiter (hot moist)

\section{Effect}

The nutfa is still and cold because of the influence of Saturn.

The embryo receives heat and begins to grow and gain flesh.

Due to the heat of Mars, the nutfa receives blood and becomes like "flesh detailed with nerves".

The embryo begins moving and its human features become apparent.

The brain, bones and skin develop.

Tongue and hearing develop.

The fetus starts moving rapidly, like the Moon. It is now complete since it has undergone all the planetary cycles.

The fetus becomes still and ailing. If a child is born in this month it cannot survive.

Perfection of life and growth.

The planet/month correlation we come across in the works of Ihwān al-Ṣafă' and 'Arīb ibn Sa'd al-Qurțubi is found widely in medical and astrological works, such as Kitāb kāmil alșinā'a al-tibbiyya ('The Complete Book of the Medical Art') by al-Mağūsī (d. 994) ${ }^{96}$ and Al-Madhal fi șinā'at ahkām al-nuğūm ('Introduction to Astrology') by Kušyār ibn Labbān (971-1029). ${ }^{97}$ However, al-Qurțubi extends his exposition of the planetary cycles to include the stages of human life in later sections. ${ }^{98}$

\footnotetext{
94 al-QURṬUBī [1956]: 37-8. According to the Qur'ān, Jesus was not crucified; rather, God spared him death and 'raised him' to heavens (Qur'ān 4: 157).

95 al-QURṬUBī [1956]: 38-9.

96 al-MAĞŪSī [1985], i: 139.

97 KUŠYĀR ibn Labbān [1997]: 156-9; BURNETT [1990]: 99.

98 al-QURȚUBī [1956]: 86.

\begin{tabular}{|c|c|c|}
\hline Age & Planet & Effect \\
\hline $1-4$ & Moon & $\begin{array}{l}\text { Weakness, wetness, ignorance, lack of opinion. The first four years correspond } \\
\text { with the four humors. }\end{array}$ \\
\hline $10-14$ & Mercury & Intelligence, thought, distinguishing, the start of attaining knowledge. \\
\hline $8-21$ & Venus & Motion of the humors, puberty, sexual desire. \\
\hline $17-41$ & Sun & Pride, honor, aspiration, maturity and responsibility. \\
\hline $15-56$ & Mars & Seeking livelihood, strife, pain, anxieties, and hardships. \\
\hline
\end{tabular}
}




\section{Conclusion}

Ptolemy in Tetrabiblos distinguishes between two "beginnings" of human life: conception, when the general characteristics of the individual are developed; and birth when personal inclinations are determined. Basing a natal chart on the moment of conception is more reliable; however, identifying it is difficult and fraught with uncertainties. ${ }^{99}$ In pseudoPtolemy's Centiloquium, a helpful tip is provided in proposition 51: the sign in which the Moon is found at the time of birth is the ascendant at conception. ${ }^{100}$ The Ihwān posit that the embryo "gets connected" in the moment and hour of conception to the celestial powers configured at that moment and becomes subject to its signs (išārāt), perhaps meaning that the astrological configuration at the time of conception - not just birth - has a signification on the life of the individual. ${ }^{101}$ The astrological configurations at the time of conception or birth obviously vary from one person to another. Notwithstanding, establishing a correlation between the planets and the months of pregnancy in the Arabic medical and astrological texts has no direct bearing on the practice of astrology, specifically genethliacal astrology. Rather, they explicate the process of individuation, from species to member, rather than prognosticate. The significance of the planets in each month is the same for all individuals as they have influence over the stages of physical development and gestation of all embryos.

Aristotle's metaphysical theories of generation and corruption, particularly his four causes (formal, material, efficient, and final), and his notions of potentiality and actuality, were applied by medieval Arabic philosophers, astrologers, and physicians to understand the roles of the male and female generative principles in conception. Texts like the Sirr alhalīqa by pseudo-Apollonius, Masqaṭ al-nutfa by Ihwān al-Ṣafā’, and astrological works such as Abū Ma'šar's Kitāb al-madhal al-kabīr differed in ascribing efficient causation to the male generative principle or the female. However, they seem to accede that the womb is the microcosmic counterpart of the universe; it is receptive to the same astral influences that actualise the generation of species, except that they are now the astral causes of conception and fetus development. Through their description of astral causality in conception, they elucidate the unity of the universe, illustrating that indeed 'as above so below'.

\section{Bibliography}

Abū Ma šar al-Balhīī $\rightarrow$ al-BALH̄ī.

Adamson, Peter / Pormann, Peter E. 2012. »On Rays«. In: The Philosophical Works of al-Kindi, Karachi: Oxford University Press, 2012: 224-5.

Baffioni provides a comprehensive analysis on embryology and astrological associations through the influence of Sirr al-halīqa on Ihwwān al-Ṣafāà, 'Arīb ibn Sa'd al-Qurțubī, al-Maǧūsī, and Abū Mačsar; see BAFFIONI [1997].

99 Ptolemy [1940], iii: 220-4.

100 HoLdEN [2008]: 78.

101 IḤWĀN AL-ṢAĀ̄̉ [2008], ii: 420.

$J A I S \cdot 16$ (2016): 181-198 
'Afī̄Ī, Abū l-'Alā. 1933. »The Sources of Muhȳī l-Dīn b. 'Arabī's Sufi Philosophy«. Bulletin of the Faculty of Arts University of Cairo, 1.

ARISTOTLE. 1984. Complete Works of Aristotle, vol. I / ed. Jonathan BARNES. Princeton University Press, Princeton, New Jersey.

BAFFIONI, Carmela. 1997. »L'influenza degli astri sul feto nell'Enciclopedia degli Ihwān al-Ṣafa’ «. Medioevo: Rivista di storia della filosofia medievale, 23 (1997), pp. 409-439.

—. 1998. »L'embriologia araba fra astrologia e medicina: Abū Ma‘šar al-Balhī e Muhammad ibn Zakarīyā' al-Rāzī «. In: FINAZZI \& VALVO (eds.) 1998: 1-20.

—. 2005. »Il rapporto astrologia-medicina nelle considerazioni embriologiche del Kitāb al-Mudhal al-kab̄ī di Abū Ma‘šar al-Balḩ̄«. In: Studi in memoria di Pier Giovanni Donini, numero monografico di Oriente moderno, 24/85: 269-285.

BALH̄̄, Abū Ma`̌̌ar al-. [1995-96]. Kitāb al-madhal al-kabìr ilā ‘ilm ahkām al-nuǧūm, ed. Richard LEMAY. 9 vols. Instituto Universitario Orientale, Napoli.

Brennan, Chris. 2009. »The Theoretical Rationale Underlying the Seven Hermetic Lots«. Tradition Journal, 2/2009: 16-27.

BuRneTt, Charles. 1990. »The Planets and the Development of the Embryo«. In: DunSTAN (ed.) 1990: 95-112.

— . 1994. »The Chapter on The Spirits«. In: BuRnETT \& JACQUART (eds) 1994: 99-120.

— / JACQuART, Danielle (eds.). 1994. Constantine the African and 'Ali ibn al-'Abbās al-Mağusi. Brill, Leiden.

DE CALlatAŸ, Godefroid. 2013. »Magia en al-Andalus: Rasā' 'il Ijwān al-Ṣafă', Rutbat al-Hakīm y Gāyat al-Hakīm (Picatrix)«. Al-Qantara, 34/2: 297-344.

Dunstan, G.R. (ed.). 1990. The Human Embryo: Aristotle and the Arabic and European Traditions. University of Exeter Press, Exeter.

EbSteIn, Michael. 2014. Mysticism and Philosophy in al-Andalus: Ibn Masarra, Ibn 'Arabī, and the Ismā̄ ìli Tradition. Brill, Leiden.

FIERRO, Maribel. 1996. »Batinism in al-Andalus: Maslama b. Qāsim al-Qurțbī (d. 353/964), Author of the Rutbat al-Hakìm and the Gäyat al-Hakìm«. Studia Islamica, 84: 87-112.

FInAZZI, R.B. / VALVo, A. (eds.). 1998. La diffusione dell'eredità classica nell'età tardo-antica e medievale. Il "Romanzo di Alessandro" e altri scritti. Edizioni dell'Orso, Alexandria.

GALEN. 1992. On Semen / ed. and trans. Philip De Lacy. Akademie Verlag, Berlin.

GoYens, Michele / DE LEEMANS / SMETS, An (eds.). 2008. Science Translated: Latin and Vernacular Translations of Scientific Treatises in Medieval Europe. Leuven University Press, Leuven.

HaQ, Syed Nomanul $\rightarrow$ Nomanul HaQ, Syed.

HIPPOCRATES. 1978. Kitāb al-ağinna li-Buqrāt / ed. and trans. M.C. LyOnS and J.N. MATTOCK. Pembroke College Press, Cambridge.

- . [2012]. Hippocrates . Vol. X, ed. and trans. Paul PotTER. Cambridge, Mass. / London: Harvard University Press.

Hiтснсоск, Richard. 1990. »Arabic Medicine: The Andalusi Context«. In: Dunstan (ed.) 1990: 7078.

HoLden, James H. 2008. Five Medieval Astrologers. American Federation of Astrology, Tempe, Arizona.

IBN LABBĀN, Kušyār $\rightarrow$ KUŠYĀR ibn Labbān. 
IBN SīnĀ. 2005. The Metaphysics of The Healing, trans. Michael E. MARMURA. Brigham Young University Press, Utah.

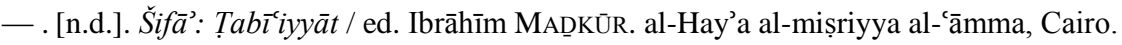

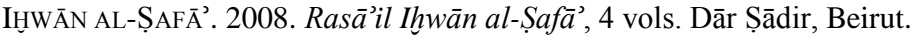

KUŠYĀR ibn Labbān. c1997. Introduction to Astrology. Institute for the Study of Languages and Cultures of Asia and Africa - Tokyo University of Foreign Studies, Tokyo.

MAĞŪSĪ, 'Alī ibn 'Abbās al-. 1985. Kitāb Kāmil al-șinā'a al-tibbiyya (The Complete Book of the Medical Art), 3 vols. The Institute of the History of Arabic and Islamic Sciences/University of Frankfurt, Frankfurt.

MASlAma b. Qāsim al-Qurțubī $\rightarrow$ al-QuRṬUBī, Maslama b. Qāsim.

Merisalo, Outi / PAHTA, Päivi. 2008. »Tracing the Trail of Transmission: The Pseudo-Galenic De Spermate in Latin”. In: GoYENS / DE LEEMANS / SMETS (eds.) 2008 : 92-104.

Musallam, Basim. 1990. »The Human Embryo in Arabic Scientific and Religious Thought «. In: G.R. Dunstan (ed.) 1990: 32-46.

Nomanul HaQ, Syed. 1994. Names, Natures, and Things: The Alchemist Jabir ibn Hayyan and His Kitab al-Ahjar (Book of Stones). Kluwer Academic Publishers, Dordrecht.

PAHTA, Päivi. 1998. Medieval Embryology in the Vernacular: The Case of De spermate. Société Néophilologique, Helsinki.

— : see also $\rightarrow$ MERISALO, Outi.

Pormann, Peter E. $\rightarrow$ AdAmson, Peter.

PSEUdo-Apollonius of Tyana. 1979. Sirr al-halīqa: Buch über das Geheimnis der Schöpfung und die Darstellung der Natur (Buch der Ursachen) / ed. Ursula WeISSER. Institute for the History of Arabic Science, University of Aleppo).

Ptolemy. 1940. Tetrabiblos / trans. F.E. RobBins. Harvard University Press, Cambridge.

Qur'ān, The. 2008 / trans. Țarīf HुĀLIDİ. Penguin Classics, London.

QuRȚUBī, 'Arīb ibn Sa'd al-. 1956. Halq al-ğanīn wa-tadbìr al-habālā wa 'l-mawlūdīn / ed. and trans. (into French) Henri JAHIER and Noureddine ABDELKADER. Ferraris, Algiers.

QurȚuBī, Maslama b. Qāsim al-. 1933. Picatrix: Das Ziel des Weisen / ed. Hellmut RitTER. B.G. Teubner, Leipzig.

SAIF, Liana. 2015. The Arabic Influences on Early Modern Occult Philosophy. Palgrave Macmillan, London.

ṬABARĪ, Abū 'l-Ḥasan 'Alī ibn Sahl Rabban al-. 1928. Firdaws al-Hikma / ed. M.Z. SidDIQI. Buch- u. Kunstdruckerei »Sonne«, Berlin-Charlottenburg.

ToELlE, Heidi. 2003. »Die Erschaffung des Menschen im Koran«. Asiatische Studien / Études Asiatiques, 57: 367-381.

VALvo, A. (ed.) $\rightarrow$ FinAzZI, R.B

(C) Liana Saif, Oriental Institute, The University of Oxford, UK

\lianasaif@hotmail.com

JAIS ・ 16 (2016): 181-198 